\title{
Research Essentials
}

\section{$38.2 \%: 119.29$}

\subsection{5\%: 108.98}

\section{6\%: 99.19}

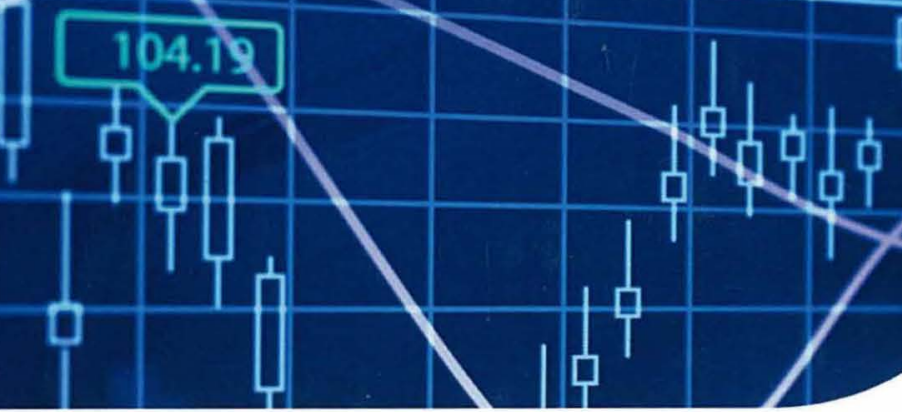

Post-Keynesian

Empirical Research

and the Debate on

Financial Market

Development 


\section{Post-Keynesian Empirical Research and the Debate on Financial Market Development}

Taha Chaiechi

James Cook University, Australia 


\author{
Managing Director: \\ Production Editor: \\ Development Editor: \\ Acquisitions Editor: \\ Typesetter: \\ Cover Design:
}

Lindsay Johnston

Jennifer Yoder

Allison McGinniss

Kayla Wolfe

Michael Brehm

Jason Mull

Published in the United States of America by

Business Science Reference (an imprint of IGI Global)

701 E. Chocolate Avenue

Hershey PA 17033

Tel: 717-533-8845

Fax: 717-533-8661

E-mail: cust@igi-global.com

Web site: http://www.igi-global.com

Copyright (C) 2014 by IGI Global. All rights reserved. No part of this publication may be reproduced, stored or distributed in any form or by any means, electronic or mechanical, including photocopying, without written permission from the publisher.

Product or company names used in this set are for identification purposes only. Inclusion of the names of the products or companies does not indicate a claim of ownership by IGI Global of the trademark or registered trademark.

Library of Congress Cataloging-in-Publication Data

Chaiechi, Taha, 1977-

Post-Keynesian empirical research and the debate on financial market development / by Taha

Chaiechi.

pages $\mathrm{cm}$

Includes bibliographical references and index.

Summary: "This book integrates the concept of financial intermediaries with Post-Keynesian macroeconomic modeling to discuss the relationship between financial markets and systems and macroeconomic development by discussing key macroeconomic variables such as investment, savings, and productivity growth"-- Provided by publisher.

ISBN 978-1-4666-6018-2 (hardcover) -- ISBN 978-1-4666-6019-9 (ebook) -- ISBN 978-1-46666021-2 (print \& perpetual access) 1. Finance--Econometric models. 2. Economic development-Econometric models. 3. Keynesian economics. I. Title.

HG106.C483 2014

$332^{\prime} .0415--\mathrm{dc} 23$

\section{4}

British Cataloguing in Publication Data

A Cataloguing in Publication record for this book is available from the British Library.

All work contributed to this book is new, previously-unpublished material. The views expressed in this book are those of the authors, but not necessarily of the publisher. 
To my parents Nasrin and Hussein for their love I know you know I am an economist Don't worry - I am a Post-Keynesian (-) 


\section{Table of Contents}

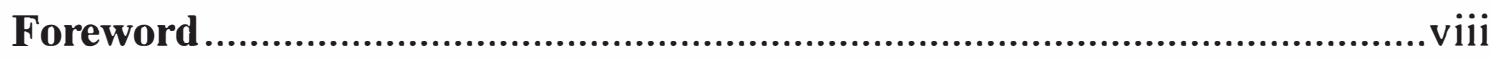

Preface

\section{Chapter 1}

Post-Keynesian Empirical Research and the Debate on Financial Market

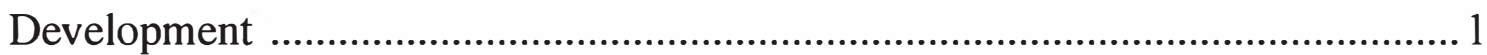

1.1 WHY THIS TOPIC? .........................................................................................................................

1.2 FINANCIAL SECTOR AND ITS DEVELOPMENT .........................................................................

I.3 RATIONALE OF THE STUDY ........................................................................................

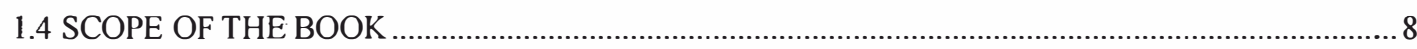

1.5 METHODOLOGICAL APPROACH AND MODELLING FRAMEWORK ……..............................

1.6 ORGANISATION OF THE BOOK .....................................................................................

1.7 SUMMARY OF THE CHAPTER ..............................................................................................

\section{Chapter 2}

Survey of Recent Development in the Literature of Financial Market

Development and Economic Growth ............................................................. 14

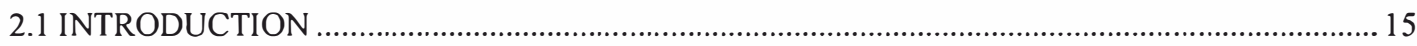

2.2 HISTORY OF FINANCE IN THE LITERATURE ….................................................................. 15

2.3 FINANCE, CREDIT AND THE RATE OF INTEREST: THEORETICAL CONSIDERATIONS ...... 17

2.4 THE 1960s: FORERUNNERS OF FINANCE-GROWTH NEXUS ..............................................2 20

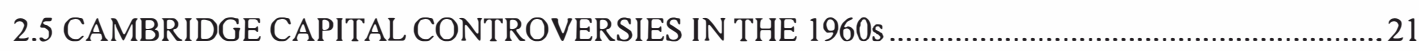

2.6 EMERGENCE OF MCKINNON-SHAW SCHOOL OF THOUGHT IN 1970s ...............................23

2.7 EVALUATION PROCESS OF FINANCIAL LIBERALISATION POLICIES EMERGES IN

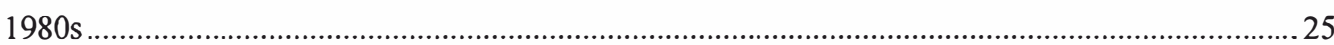

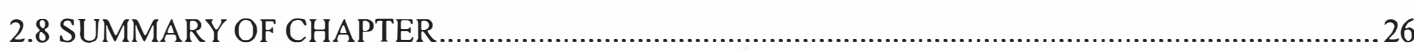




\section{Chapter 3}

Endogenous Growth Theory and Financial Sector …….....................................32

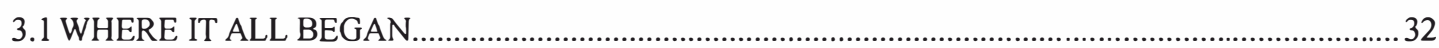

3.2 ENDOGENOUS GROWTH MODELS AND ENDOGENOUS MONEY MODELS ……………........ 34

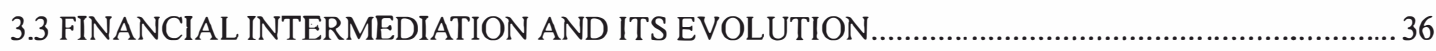

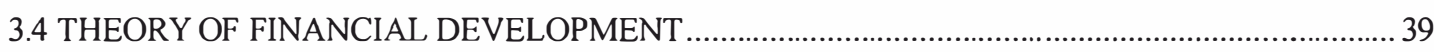

3.5 FINANCIAL MARKETS DEVELOPMENT AND ECONOMIC GROWTH …………................... 42

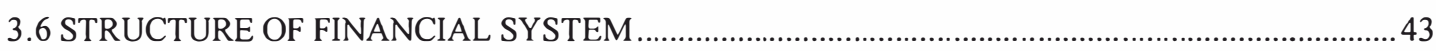

3.7 EMPIRICAL EVIDENCES OF FINANCIAL DEVELOPMENT AND ECONOMIC GROWTH....... 47

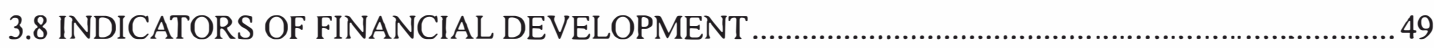

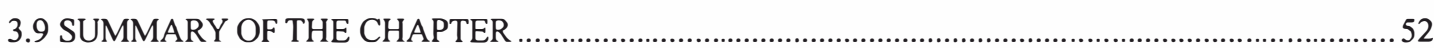

\section{Chapter 4}

Post-Keynesian Macroeconomic Models ..........................................................61

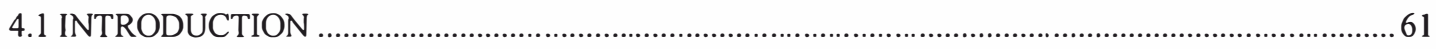

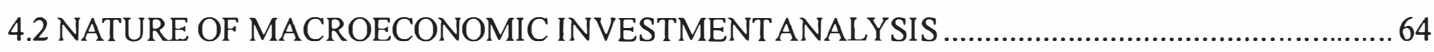

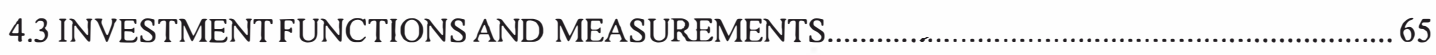

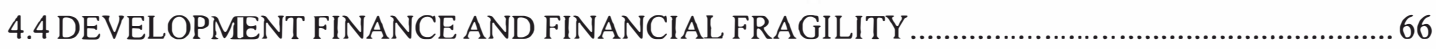

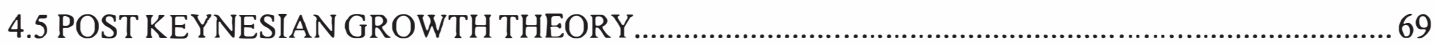

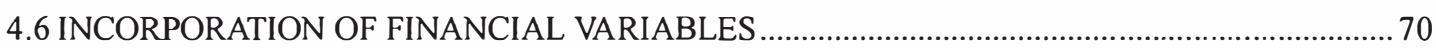

4.7 THE ROLE OF INTEREST RATES IN POST KEYNESIAN GROWTH MODELS ……................... 74

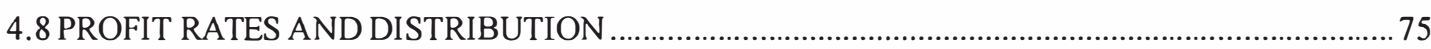

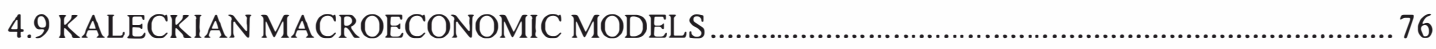

4.10 RATE OF INTEREST AND PROFIT IN KALECKIAN MODEL_............................................... 77

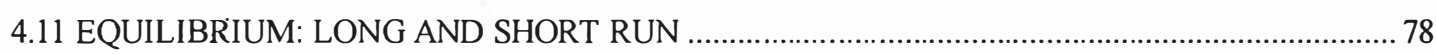

4.12 CONVERGENCE FROM SHORT-RUN TO LONG-RUN ................................................................ 80

4.13 THE KALECKIAN GROWTH MODEL: THE STAGNATIONIST VERSION................................. 81

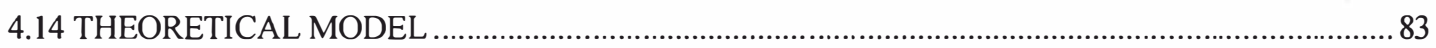

4. I 5 COMMUNALITY BETWEEN POST-KEYNESIAN GROWTH AND NEW GROWTH

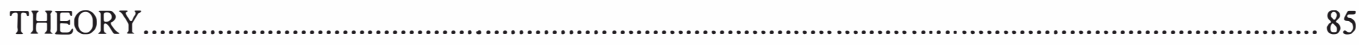

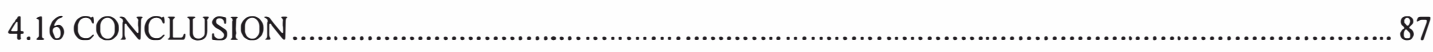

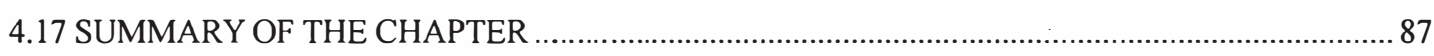

\section{Chapter 5}

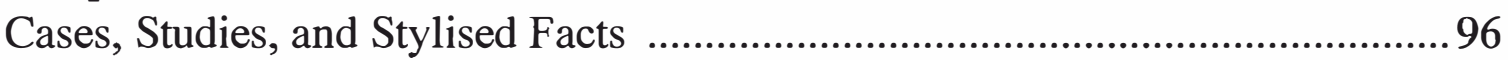

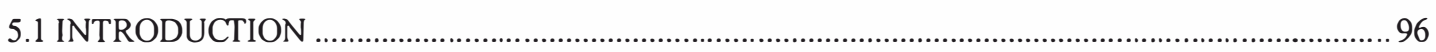

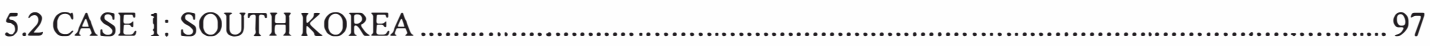

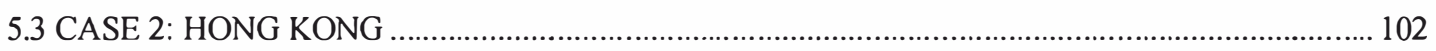

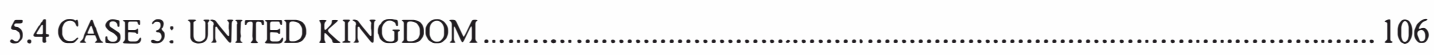

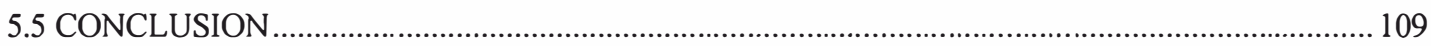

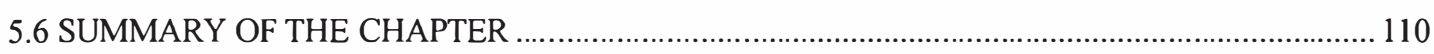




\section{Chapter 6}

Model and Model-Driven Methodology ........................................................... 115

6.1 INTRODUCTION ................................................................................................................ 115

6.2 THE THEORETICAL MODEL .............................................................................................. 116

6.3 THE NATURE OF FISCAL POLICIES IN ADVANCED AND DEVELOPING ECONOMIES....... 123

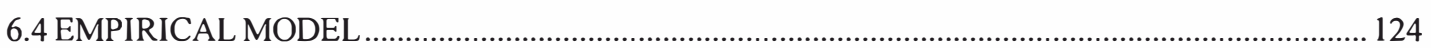

6.5 THE FINALISED ECONOMETRIC MODEL .........................................................................

6.6 ESTIMATION TECHNIQUES.............................................................................................. 129

6.7 PRE-ANALYSIS...................................................................................................................... 130

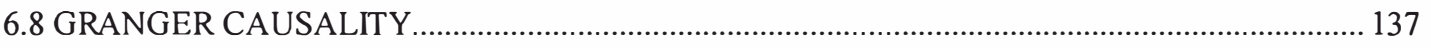

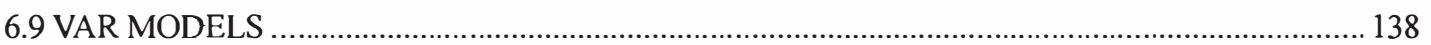

6.10 WHAT IS A SVAR MODEL? .................................................................................................. 140

6.11 ORTHOGONALISING VARS /IMPULSE RESPONSE FUNCTION........................................... 147

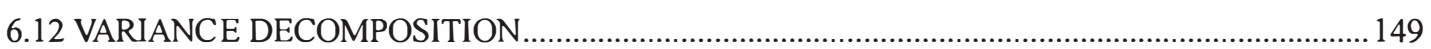

\section{Chapter 7}

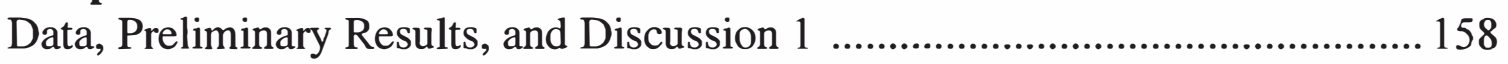

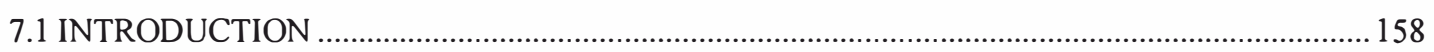

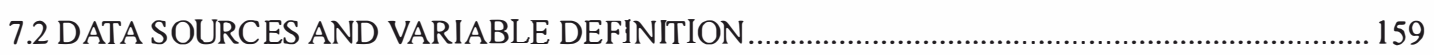

7.3 DATA SET CHARACTERISTICS ............................................................................................... 163

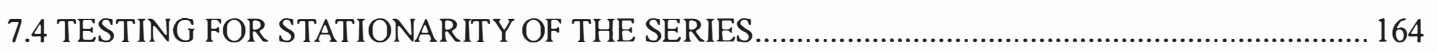

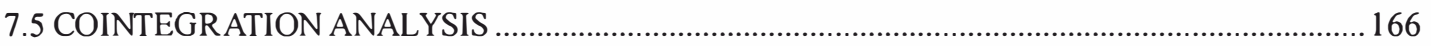

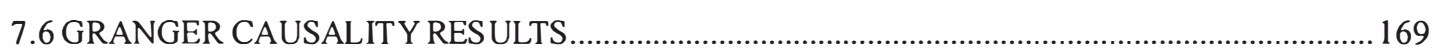

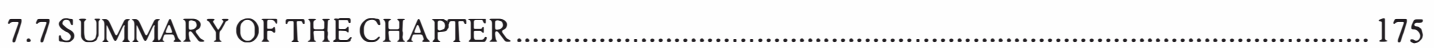

\section{Chapter 8}

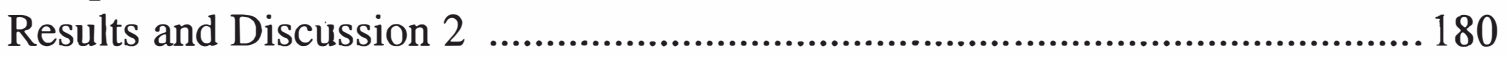

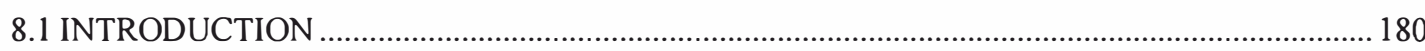

8.2 SETTING UP A TRADITIONAL VAR..................................................................................... 182

8.3 STRUCTURE AND IDENTIFICATION ISSUES ................................................................... 184

8.4 EXOGENEITY ISSUE AND PAIR WISE GRANGER CAUSALITY ........................................... 188

8.5 SVAR IDENTIFICATION AND ESTIMATED MATRICES …………………………………......... 193

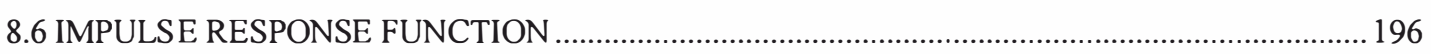

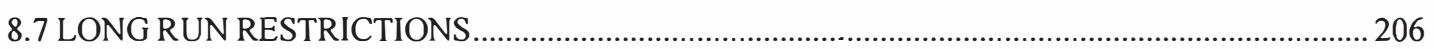

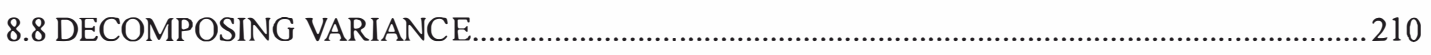

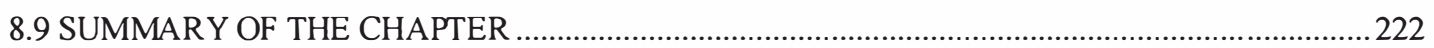

\section{Chapter 9}

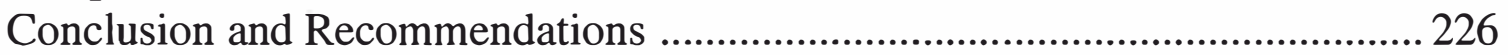

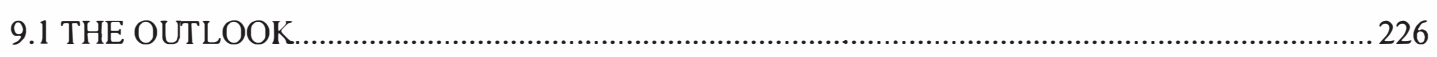

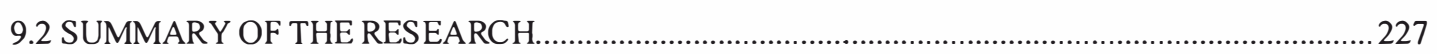

9.3 POLICY IMPLICATIONS AND RECOMMENDATIONS ............................................................. 233

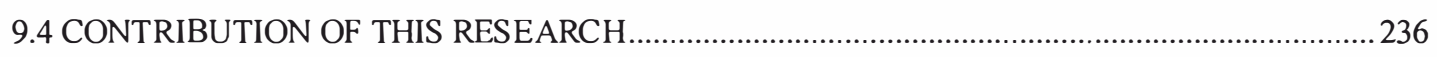

9.5 LIMITATIONS OF THE STUDY AND FUTURE RESEARCH....................................................... 237 
Appendix 1: Data Characteristics and Descriptive Statistics

Appendix 2: Johansen Cointegration

Appendix 3: Bivariate Granger Causality .

Appendix 4: Estimated SVAR Models.

Appendix 5: Results of Variance Decomposition ............................................268

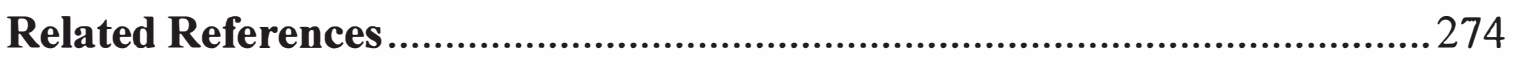

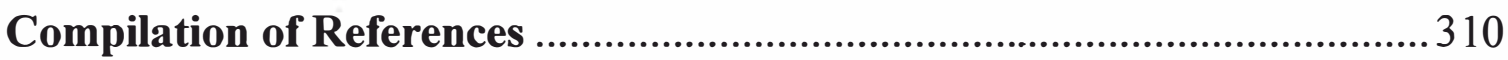

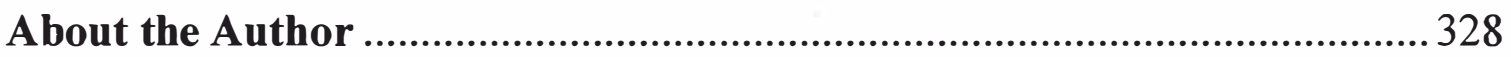

Index 


\section{Foreword}

Recent years have evidenced a burgeoning of quantitative forms of modelling within the Post-Keynesian tradition. Over much of the Post-WWII period, Keynesian economics has contributed to the development of National Income Accounting and has assisted in the construction of large-scale econometric models for policy analysis and evaluation. Nevertheless, the appearance of the seemingly inexplicable phenomenon of "Stagflation," characterised by a resilient combination of high rates of inflation with high levels of unemployment, assisted in the intellectual rise of Monetarism is the early 1970s and the subsequent "Rational Expectations Revolution." Young economics graduates were soon attracted by new modelling frameworks such as Real Business Cycle Theory and its successors, while the New Keynesian synthesis offered a welter of different kinds of market failure that could move the economy temporarily away from its conditions of optimal growth. Somewhere in this proliferation of efficiency wage, Big " $\mathrm{S}$ " and little " $\mathrm{s}$ " inventory, and creditrationing models, the point of effective demand seemed to disappear from view entirely (for example, see Blanchard \& Fisher, 1990).

Meanwhile, Post-Keynesian side research seemed to languish, in part, due to a shared conception amongst certain eminent Post-Keynesian economists that quantitative modelling was ill-suited to the task of grasping what was essential about the Keynesian vision. Hyman Minsky, for his part, emphasised the importance of financial fragility, occasioned by loss of diversification, increasingly deferred (present value) payback periods, and increasing reliance on external finance on the part of banks, households, and firms. This is precisely the point where Minsky's (1985) famous analysis of transitions between hedge, speculative, and Ponzi financial positions comes into play.

For Paul Davidson, one of the editors of the Journal of Post-Keynesian Economics, it was Keynesian notions of fundamental uncertainty and fluctuations in animal spirits that were deemed to be responsible for unpredictable shifts in the key behavioural parameters of the macro-economy, including those governing the preference for liquidity, the position of marginal efficiency of capital schedule, 
and the marginal propensity to save out of household disposable income. These fluctuations rendered the Keynesian vision opaque to more conventional forms of statistical and mathematical analysis. Here, it would seem, the responsibility for such an implacable stance could be sheeted home to Keynes who, during in his debates with Jan Tinbergen over the validity of econometric modelling, had complained vehemently about a lack of sufficient homogeneity on the part of the available data. Opinions still vary widely as to what Keynes actually meant by this observation, but uncertainty and financial fragility play an undoubted role.

In Development Economics too, the application of both static and dynamic versions of input-output modelling, which readily lent themselves to a straightforward Keynesian interpretation in terms of effective demand, were soon displaced by neoclassical computable general equilibrium modelling, with input-output modules consigned the hum-drum task of determining the aggregation of intermediate inputs into production. In its emphasis on the importance of financial institutions, the strand of literature dealing with financial development represents an exception to the dominant focus of the orthodoxy in development economics, even though members of both the Post-Keynesian and more orthodox tradition have contributed to the debate, one which gained increasing impetus after the mid-1990s Asian Financial Crisis, pitting anti-dirigiste neoliberals against advocates of the interventionist developmental state. Foucault's 1978-1979 lectures at the Collège de France clearly reveal that neoliberalism, in both its German Ordoliberal and Chicago School versions, was firmly pitted against Keynesianism. For the German neoliberals, demand management, central planning, and the imposition of price controls were the thin edge of the totalitarian wedge. From the American neoliberal perspective, whose political orientations were constituted in the aftermath of the War of Independence, Keynesian interventions were viewed as the external imposts of a military and imperial state. In the person of Milton Frieman, the Chicago tradition found an ardent advocate of Monetarist principles in the field of macroeconomic policy.

Ironically, though, it was the very debates between Monetarists and Keynesians in the early 1980s over the relative effectiveness of monetary or fiscal policy that gave so much impetus to the development of modern time-series econometrics, including co-integration analysis, error correction modelling, and diagnostic testing for the validity and reliability of estimates. At the same time, quantitative modelling and simulation was making impressive forward strides. While any review of these developments must of necessity be partial and incomplete, it is important to appreciate the diversity of Post-Keynesian offerings and the prospects for reconciling previously opposed perspectives.

Researchers such as Peter Skott (1989) and Taylor and O'Connell (1985) constructed formal models to explicate Minsky's analysis of financial instability. 
Meanwhile, building on the earlier work of Robinson (1952), Kalecki (1937), and Steindl (1952), Kaleckians, such as Amitava Dutt (1995), were composing theoretical models of accumulation, which emphasized the importance of finance and debt. In his Minskyan model, Tymoigne (2006) distinguishes between short-term and long-term borrowing, using a system dynamics approach, illustrated with block-flow diagrams. However, as Lavoie (2008) cautions, "[h]is feedback reaction functions are highly complex, but his diagrams are rather hard to interpret."

Taking off from foundational work with the Cambridge Economic Growth Project (Godley \& Cripps, 1983), Wynn Godley and Marc Lavoie (2007) have published a major text on Stock-Flow-Consistent approaches to modelling the macro-economy. For Lavoie (2008), this approach affords the prospect of reconciling what he calls both the Cambridge (which he associated with the Kaleckian or Kaldorian and the neo-Ricardian or Sraffian strands of post-Keynesian thought) and the "Wall Street views" (of the American "Fundamentalist" Post-Keynesians such as Paul Davidson and Hyman Minsky) (Dos Santos, 2005; Eatwell, Mouakil, \& Taylor, 2008; Treeck, 2008).

At the New School of Social Research, Anwar Shaikh was engaged in the development of a coherent Classical approach to modelling accumulation and growth, which integrated both the short-run and long-run, while avoiding the Marshallian temptation to conceive of the former as Neoclassical and the latter as Classical. More recently (Shaikh, 2009), he has concentrated on the need to reconcile both Keynesian and Harrodian approaches to macroeconomic growth. The focus of his concerns are two central propositions: first, that a rise in investment will raise equilibrium output via the multiplier; and, second, that a fall in savings rate will raise equilibrium output in accordance with the "paradox of thrift" narrative (Shaikh, 2009, p. 456). In adopting a longer-run setting, Shaikh observes that investment not only creates demand but also raises capacity. From this perspective, he contends that the only self-consistent path for accumulation is one generating output growth at the Harrodian warranted rate. On the basis of this reasoning, he recommends that investment equations be modified accordingly. Those working within this Harrodian tradition also highlight the importance of articulating the relationship between successive short-run and long-run outcomes (Skott \& Ryoo, 2008a, 2008b). Of course, if private sector investment always achieved the warranted rate of growth, there would be no need for Keynesian policies of job creation. Building on Shaikh's Harrodian base, Chatelain (2010) has performed the useful task of incorporating credit rationing into a Stock-Flow-Consistent modelling framework, thus accounting for departures of investment from rates required to achieve the warranted growth path.

Taha's book focuses on issues of financial development over the longer-term. To this end, Taha draws upon the Structural Vector Autoregressive (SVAR) modelling 
of Stockhammer and Onaran. Their parsimonious Kaleckian approach is long-run insofar as it accounts for such things as productivity growth.

The financial system is always a double-edged sword. Sophisticated financial institutions help to mobilise savings and allocate financial resources to sites and projects where they can achieve the highest economic return. The very same institutions, however, can be a source of speculative excess, asset price inflation, and instability. Of course, while it is difficult to account for the prudential influence of regulatory agencies in a macroeconomic setting, aspects of fiscal sustainability certainly can be accommodated. More broadly, a developmental state can assume the role played by the head office of a multidivisional enterprise in managing its subsidiaries by effectively allocating funds to areas that will realize the highest social return. In this manner, Chandler's insights into the important role of corporate organizational forms are thus extended to encompass key institutions of state such as economic development boards. Taha's thesis helpfully reviews this literature on the developmental state.

In the aftermath of the Global Financial Crisis (GFC), issues of fiscal sustainability are coming to the fore. Conservatives argue for a necessary return to fiscal conservatism in the form of budget surpluses. Keynesians argue the need for ongoing deficit spending in the US economy to prevent a double-dip recession and restore buoyant global-economic conditions. From the "modern money" perspective (Wray, 1998) endorsed by Taha, budget surpluses are seen to be responsible for the destruction of real wealth, at the same time forcing the non-government sector into deficit, thus eroding the sustainability of non-government balance sheets. At the same time, the real wage repression occasioned by two decades of neoliberal policies has undermined sustainability in countries like the US, where rates of accumulation were maintained through the expansion of credit, increasingly to those less and less likely to repay. In my own research, an important objective is to incorporate detailed government sector accounts into a stock-flow-consistent model (Juniper \& Mitchell, 2008). In Stockhammer's more recent work (2009), a Kaleckian approach to macroeconomic modelling has clearly helped to inform his thinking about these sources of financial crisis. He argues (Stockhammer, 2009, p. 1) that:

[t]he combination of real wage moderation and financial liberalization has led to different strategies (or at least outcomes) in different countries. While some countries (like the USA) exhibit a credit-fuelled consumption-driven growth model that comes with large current account deficits, others (like Germany and Japan) show an export-driven growth model with modest consumption growth and large current account surpluses. 
In my view, Taha made important contributions to debates of this kind about appropriate policy responses to moderate and avoid the repeat of financial crises on such a scale in the future.

James Juniper

University of Newcastle, Australia

James Juniper is an Economics Lecturer and Research Associate of the Centre of Full Employment at the University of Newcastle, Australia. He supervises and conducts research on Post-Keynesian macroeconomics along withregionaldevelopment and environmental economics from a Post-Keynesian perspective. He is completing a book examining the implications of process philosophy for the social sciences, which draws on the works of Gilles Deleuze, Alain Badiou, and Alfred North Whitehead.

\section{REFERENCES}

Blanchard, O. J., \& Fischer. (1990). Lectures on Macroeconomics. London: The MIT Press.

Chatelain, J.-B. (2010). The Profit-Investment-Unemployment Nexus and Capacity Utilization in a Stock-Flow Consistent Model. Metroeconomica, 61(3), 454-472. doi:10.1111/j.1467-999X.2009.04074.x

Chiarella, C., \& Flaschel. (2000). The Dynamics of Keynesian Monetary Growth: Macro Foundations. Cambridge, UK: Cambridge University Press.

Dos Santos, C. H. (2005). A stock-flow consistent general framework for formal Minskyan analyses of closed economies. Journal of Post Keynesian Economics, 27(4), 711-735.

Dutt, A. K. (1995). Internal finance and monopoly power in capitalist economies: A reformation of Steindl's growth model. Metroeconomica, 46(1), 16-34. doi:10.1111/j.1467-999X.1995.tb00724.x

Dymski, G. A. (2010). Why the subprime crisis is different: a Minskyian approach. Cambridge Journal of Economics, 34(2), 239-255. doi:10.1093/cje/bep054

Eatwell, J., Mouakil, T., \& Taylor, L. (2008). Liquidity, Liverrage and the impact of sub-prime turbulence. Centre for Finanacial Analysis and Policy, Judge Business School, University of Cambridge.

Foucault, M. (2008). The Birth of Biopolitics: Lectures at the College de France, 1978-1979. Hampshire, UK: Palgrave, Macmillan. doi:10.1057/9780230594180 
Godley, W., \& Cripps, F. (1983). Macroeconomics. London: Fontana.

Godley, W., \& Lavoie, M. (2007). Monetary Economics: An Integrated Approach to Credit, Money, Income, Production and Wealth. London: Macmillan.

Juniper, J. \& Mitchell. (2008). There is no financial crisis so deep that cannot be dealt with by public spending (Working Paper No. 08-10). Newcastle, Australia: Centre of Full Employment and Equity, The University of Newcastle.

Lavoie, M. (2008). Towards a post-Keynesian consensus in macroeconomics: Reconciling the Cambridge and Wall Street views. Paper presented at the 12th Conference of the Research Network Macroeconomics and Macroeconomic Policy, Macroeconomic Policies on Shaky Foundations-Wither Mainstream Economics. Berlin, Germany.

Minsky, H. P. (1985). The Financial Instability Hypothesis: A Restatement. In Post Keynesian Economic Theory: A Challenge to Neo-Classical Economics. Sussex, UK: Wheatsheaf Books.

Shaikh, A. (2009). Economic Policy in a Growth Context: A Classical Synthesis of Keynes and Harrod. Metroeconomica, 60(3), 455-494. doi:10.1111/j.1467999X.2008.00347.x

Skott, P., \& Ryoo, S. (2008a). Financialisation in Kaleckian economics with and without labor constraints (Working paper 2008-05). Amherst, MA: University of Massachusetts.

Skott, P., \& Ryoo, S. (2008b). Macroeconomic implications of financialisation. Cambridge Journal of Economics, 32(6), 827-862. doi:10.1093/cje/ben012

Stockhammer, E. (2008). Some Stylized Facts on the Finance-dominated Accumulation Regime. Compettition \& Change, 12(2), 184-202.

Stockhammer, E. (2009). The finance-dominated accumulation regime, income distribution and present crisis (Working Paper Series No. 127). Department of Economics, Vienna University of Economics \& B.A.

Taylor, L., \& O'Connell, S. A. (1985). A Minsky Crisis. The Quarterly Journal of Economics, 100, 871-885.

Treeck, T. V. (2008). A synthetic, stock-flow consistent macroeconomic model of 'financialisation'. Cambridge Journal of Economics, 27(1), 1-27.

Tymoigne, E. (2006). The Minskyan System, Part III: System Dynamics Modeling of Stock-Flow-Consistent Minskyan Model (Working Paper No. 455). Annandaleon-Hudson, NY: The Levy Economics Institute of Bard College. 
xiv

Tymoigne, E. (2009a). Central Banking, Asset Prices and Financial Fragility. London: Routledge.

Tymoigne, E. (2009b). Securitization, Deregulation, Economic Stability, and Financial crisis, Part II Deregulation, the Financial crisis, and Policy Implications. The Levy Economics Institute of Bard College.

Vercelli, A. (2009a). Minsky Moments, Russel Chickens, and Gray Swans: The Methodological Puzzles of the Financial Instability Analysis. Annandale-on-Hudson. NY: The Levy Economics Institute of Bard College.

Wray, L. R. (1998). Understanding Modern Money: The Key to Full Employment and Price Stability. Chettenham, UK: Edward Elgar. 


\section{Preface}

In recent studies, the importance of financial markets has been highlighted, and financial systems have been ascribed an increasing influence over real sector development. However, most of these discussions fail to adequately integrate this relationship into a general and theory-based macro-economic model. The research questions that arise are: "Whether financial development affects real economic activities?" and "Does the structure of the financial system matter for economic growth outcome?" Thus, the main objective of this research book is to explore the interaction between financial market development and the indicators of real economy (such as investment, savings, unemployment, productivity growth, etc.) in applied context of macro-theory of economic growth for selected open economies. To identify appropriate and accommodative theories of economic growth, the book touches a wide range of issues related to orthodox and heterodox theories of economic growth, financial devclopment, financial fragility, macroeconomic modelling, and data handling issues. We focus on the impressive transformation process that growth theories have gone through over the past several decades without overlooking the existing gaps in relation with financialisation of current models and lack of integration of financial sector into real sector macro models.

The book chooses three countries as case studies, including Hong Kong, South Korea, and the UK, and it investigates how financial systems differ across these cases given the significant differences in their market structures. The market structure for financial system and services differ between these three cases, with the most striking difference being the degrees of public sector ownership and control and stock market activities, so none of these selected markets represent homogeneity in relation to their financial sectors. The book examines channels through which the financial markets of these economies affect the real economy using time series data by applying advanced econometric techniques. One result is that almost half of this book is devoted to application of econometric theory and data characteristics to examine formal economic theory. All of the techniques illustrated in the book need 
to be explicitly programmed. Accordingly, the econometric analysis and graphics in this book is carried out using EViews software. This book presents hands-on examples for a wide range of econometric techniques, from stationarity analysis to system of simultaneous equations using time series data and post-Keynesian macroeconomic model. Throughout this book, we have tried to return to the research objectives introduced in chapter 1 as often as possible.

The literature presented in this book suggests that money supply, credit availability, and stock market capitalisation are among the most important indicators of financial market development, which can help financial systems preserve overall stability to an extent. We contributed to this body of literature by undertaking important empirical research using these indicators to identify the resilience and health of financial systems if they face a sudden external shock or a financial crisis.

This book is unique in terms of integrating the concept of the theory of financial intermediaries with the post-Keynesian macroeconomic modeling. This integration accounts for the role of the banking system, credit market, and stock market capitalisation in stimulating the aggregate demand. In addition, the results of the empirical analysis provide insights into the macro-economic functioning of selected countries considering their productive but uneven financial market structures, different levels and degrees of government ownership, and state control on the financial systems.

Against this background, the book starts with emphasising the fact that while recent studies suggest that financial intermediation affects growth through various channels, a great deal of research fails to effectively examine this relationship within a general macroeconomic framework. Chapter one focuses on the absence of such attempts and provides a brief definition of financial sector development, concluding that the financial séctor can be called developed if the efficiency, stability, and competitiveness of the sector improve. Consequently, research questions arise, and the main objectives of the research are discussed. The significance of this study is addressed in terms of integrating the financial sector with the real sector in a comprehensive macroeconomic model in post-Keynesian tradition, and in terms of econometric techniques that enable the research to address simultaneity issues among variables.

Chapter two moves on to early studies that highlighted the importance of finance and its importance on some growth aspects. Releasing the process of finance in different schools-neo-classical, monetarist, and Keynesians-is discussed in this chapter as well. Other issues on governing the credit and capital markets from a Keynesian point of view and Marx's ideas on the financial variables are deliberated. Post-Keynesian logic concerning the system of credit money and the accountability of commercial banks for the creation of money and credit are presented. Features 
and the rationale of the McKinnon and Shaw's school on the importance of credit market and financial institution in the growth process are explored in detail.

The theory of financial intermediation is discussed in chapter three. The most common indicators of financial development are introduced along with the review of some empirical analyses. Later in the chapter, a conceptual distinction between bank-based and market-based financial markets is made. Bank-based market is an outcome of the positive role of banks in development and growth. The chapter describes how in such financial systems banks can finance development more effectively than markets in developing economies and, in the case of state-owned banks, how market failures can be overcome and allocation of savings can be undertaken strategically.

The purpose of chapter four is to review the post-Keynesian macroeconomic theories and models. In general, post-Keynesian growth theories argue that economic growth is demand-driven in the short-run and medium-run, and that investment acts as a generator to promote the other sectors within the economy and enhances economic growth. Since expectations are very important in investment decisions, post-Keynesian economists argue that profit shares should enter into the macro models to capture the role of expectations. Against this background, this chapter starts with an extensive discussion on the nature and characteristics of investment function in different approaches. Later in the chapter, the incorporation of financial variables such as interest rate, capacity utilisation, and profit rates into postKeynesian growth models and distributions are deliberated. In line with the goal of our research, which is extending a model to take into account financial variables, the desired empirical and theoretical approach in this book is Kaleckian-Post-Keynesian models of growth and distribution. Accordingly, a Kaleckian-Post-Keynesian model incorporating financial sector and interest rates is introduced, and the characteristics of this approach are conferred.

Chapter five moves on to specify characteristics of the financial markets of three remarkable cases studies, namely South Korea, Hong Kong, and the United Kingdom. This chapter investigates how financial systems differ, and how are they are similar across these countries. Hong Kong and the United Kingdom have comparatively large, active banking systems. On the particular measure of stock market development, Hong Kong and the United Kingdom are classified as well developed; South Korea has an active but small stock market. In terms of overall financial sector efficiency, all three countries stand out and are ranked very highly. The chapter concludes that despite differences, there is an important similarity between R-banking and A-banking: in both systems, financial intermediaries are privately owned. This results in competition among agents to provide financial resources to firms. Consequently, no single agent will control whether a given investment project may go 
forward, increasing the probability that, ultimately, good projects will be selected by the mechanisms of the financial system, while the good projects are selected by the government authorities in the hard budgeting type of market.

Chapter six extends a particular Kaleckian-Post-Keynesian model to include the financial sector; the model consists of behavioural functions for investments, saving, and international trade defining the goods market and the producer's equilibrium curve, which relates capacity utilisation to the distribution of income. Producer's equilibrium is not only determined only by the pricing behaviour of firms but also by a reserve army effect in a Marxian sense, reflecting the bargaining power of the workers. Interest rate is an exogenous variable for the investment process and is determined by the policy of the central bank and by the liquidity preference of commercial banks and monetary wealth holders. The chapter justifies the exogenous inclusion of financial development indicators into investment, savings, and productivity growth equations followed by the theory of financial intermediation, which fundamentally is the main contribution of this research to the literature and empirical works. The methodological approach adapted in this research is a Structural Vector Autoregression (SVAR) model that is used to examine the relationship between exogenous financial development indicators and a system of equations for key macroeconomic growth indicators, using quarterly data for periods ranging from 1990 to 2010. This was done in a series of steps and pre-analysis testing, such as stationarity, cointegration to determine the existence of long-run relationships between the variables, and Granger causality.

Chapter seven is devoted to definitions of the model variables and the process in which the data were generated. The data were obtained from the various issues of the International Financial Statistics (IFS-IMF), International Labour Organisation (ILO), World Bank Database (WDI), and Asian Development Bank (ADB) for the period of 1990:Q1 to 2010:Q4 for South Korea. All data have been seasonally adjusted, and in the case where some variables were only available on an annual basis, the quarterly data were generated using different techniques. The model variables from the system of equations, including investment, savings, income distribution, unemployment, productivity growth, and net export as endogenous variables and interest rate, capacity utilization, and indicators of financial development (monetisation ratio, domestic credit, and stock market capitalisation) as exogenous variables, as already has been explained in a previous chapter. This chapter further tests staionarity on all the variables, and then it moves on to test for cointegration applying Johansen-Juselius approach for each of the equations in the model for all three countries separately. To evaluate whether including certain variables in the VAR makes sense, a Granger causality test is carried out in this chapter as well. 
Chapter eight starts with explanation about the mechanism of setting up an unrestricted VAR and presents VAR residual tests for every equation in the system for each country separately. Later in the chapter in order to be able to plot impulse response functions based on the orthogonal shocks, a Structural VAR model is estimated by taking into account short-run restrictions - the ordering of which was derived from Kaleckian-Post-Keynesian theory. The initial assumption is that the financial development variables are exogenous to the movements in growth variables. However, the imposition of exogeneity condition was tested (using the block exogeneity Wald test) in chapter seven to ensure its compatibility with our macroeconomic data.

To avoid any seriousmisspecification, short-run restrictions are imposed by adopting Choleski decomposition to investigate the contemporaneous relationship between the variables. The results of SVAR allow us to conclude that the post-Keynesian model seems to perform well and in line with the theoretical model. Chapter eight continues the analysis by investigating impulse responses. Since SVAR is built on the Choleski decomposition ordering, where the ordering of the variables entering the model plays a significant role, the impulse response functions are scaled by the inverse of the Cholesky factor of the residual covariance matrix to orthogonalise the impulses. The impulse response analysis in this chapter incorporates the effect of different financial regimes which shed more light on the determinants of accumulation, savings, and productivity.

In addition, this chapter investigates the effect of variance decomposition of the indicators of financial development in the case study countries that would better account for the link between financial variables and other key macroeconomic variables, and separates the variation in the indicators of financial development into the component shocks to the model. According to our empirical findings, the stock market capitalisation contribution to overall economic development progressively exceeds that of other indicators of financial development adopted in this study (monetisation ratio and domestic credit). The effects from financial development on investment savings and productivity growth have been almost observed in all cases. However, two indicators used to measure financial development, the monetisation ratio and the domestic credit availability, both as a share of GDP, have failed to show any clear effect in the United Kingdom adopting the SVAR method of estimation.

Chapter nine summarises the key research findings and discusses the possible channels through which financial sector development could potentially affect the economic growth process. The chapter further highlights contributions of this research to growth studies, discusses policy implications arising from the findings of this research, and provides directions for future research and analysis. The research ends with concluding remarks. 


\section{WHO SHOULD READ THIS BOOK?}

The intended audience for this book is the faculty, top experts in macroeconomic modelling, and higher degree research students who are interested in a broader knowledge of modern theories of economic growth and distribution. Particularly, the book may be useful for researchers who require an intermediate and upper-intermediate understanding aboutstatistical andeconometric tools, which are frequently employed in the area of finance and macro-econometrics.

Since the book reviews and covers a fairly large body of literature on financial markets and their roles in the development of real economy, it can be used for postgraduate courses covering the history of economic thoughts with a focus on issues such as capital controversy, financial markets, and economic growth. Selected chapters of this book can be used in advanced courses with a focus on Keynesian and post-Keynesian theories of growth and distribution.

Although the motivation formodelling in this book is derived from post-Keynesian growth theory and the theory of financial development, the empirical testing of these theories using time series estimation techniques may prove useful for postgraduate research students and researchers dealing with time series data from many other disciplines and schools of thought.

In order to fully comprehend the analytical materials presented in this book, readers are recommended to have introductory knowledge of time series econometrics. However, this is not essentially a prerequisite, since these materials are explained systematically in relevant chapters.

\section{FINAL WORD}

In spite of all my efforts, errors have indubitably crept into the text; if this edition is of any guide, the numbers may be embarrassingly large. I would be grateful for suggestions for improving the organisation, style, and clarity of the manuscript. 


\section{THIS BOOK AT A GLANCE}

Content Level: Research, Applied research

Key Words: Financial market development, Post-Keynesian Theories of economic growth and income distribution, Time series data analysis, Structural Vector Autoregression model, Impulse response analysis, variance decomposition

Related Courses: Advance Macroeconomics, Intermediary to Advance Econometrics Highlights: This book:

- Presents advanced quantitative approaches to dynamic modelling of simultaneous equations systems.

- Provides insight into the working and interaction of Kaleckian postKeynesian macro-dynamic contemporaneous feedback effects.

- Proposes theoretical, empirical, and numerical treatment of large macroeconomic databases.

Taha Chaiechi

James Cook University, Australia 



\title{
Chapter 1 \\ Post-Keynesian Empirical Research and the Debate on Financial Market Development
}

\begin{abstract}
Literature suggests that financial intermediation affects growth through various channels. The questions, however, are "Whether financial development affects real economic activities?" and "Does the structure of the financial system matter for the economic growth outcome?" The aim of this chapter is, therefore, to briefly describe the concept of financial market development by highlighting the important role of the financial sector in the development of the real sector. Later in the chapter, the scope of the book is discussed, and research objectives are identified.
\end{abstract}

\subsection{WHY THIS TOPIC?}

The fundamental question in economic growth that has preoccupied economists is why different economies grow at different rates. The theoretical and empirical literatures have come up with a number of theories and explanations for this, however, most of the early literature considered real sector aspects rather than financial aspects of economic development. Later theoretical and empirical literature revealed 
that a thorough and effective financial system is essential for economic development and growth. The financial systems are subject to boom and bust cycles which often has consequences for the real economy. Furthermore, the political structure of economies which are repeatedly influenced by preceding experiences plays an important role in shaping the structure and development of the financial system.

So important questions are raised: "What is the role of financial sector in marketbased and/or bank-based economies," "How does financial sector influence the growth process of countries?," "Does the structure of financial sector matter?." Such questions were largely ignored in the early growth literature. Nevertheless, there are a few numbers of ground-breaking works in the 60s and 70s which built foundation for the finance-growth nexus. Since 1990s a innovative strand of literature explored relative importance of banks and markets, and introduced the concept of "financial development." In this book we discuss each in turn.

Since the collapse of fixed exchange rate in the early 1970s, international financial system regimes underwent major changes and transformations, and development finance emerged as a discipline within the general area of economics, which attracted significant theoretical and empirical analyses.

Since the writings of John Stuart Mill in the mid-1800, many economists have argued either that finance is unimportant or that it matters most when it gets out of order (Caprio, 1998). Generations of economists constructed models without money or a financial sector. However, with the explosion of banking and financial crises (such as the 1997 crash and the GFC) around the globe finance is back as an important element in the course of economic development. Over the past thirty years, a great deal of attention has been paid to the role of financial markets in the process of economic growth. The importance of financial markets has been highlighted in the recent literature and financial systems have been recognised via their increasing influence over real sector development.

GFC was another trigger for financial systems to evolve even more substantially. As a result of such evolutionary changes one can borrow greater amounts at cheaper rates than ever before; invest in a multitude of instruments catering to every possible profile of risk and return, and share risks with strangers from across the globe. Technological progress has reduced the cost of communication and computation, as well as the cost engineering techniques from securitisation to credit scoring, is now widely used. Deregulation has removed artificial barriers preventing entry, or competition between products, institutions and markets (Rajan, 2005). Finally, the process of institutional change has created new entities within the financial sector such as private equity firms and hedge funds, as well as new political, legal, and regulatory arrangements. 
Before the GFC financial markets had expanded too large uncontrollably and had become much deeper. The broad participation has allowed risks to be more widely spread throughout the economy. The expansion in the variety of intermediaries and financial transactions has major benefits, including reducing the transaction costs of investing, expanding access to capital, allowing more diverse opinions to be expressed in the marketplace, and allowing better risk sharing (Rajan \& Zingales, 2003; Shiller, 2003).

According to the large body literature, in the context of the broad and significant performance of financial markets (discussed in detail in the following chapters), there are several ways by which the financial system can affect the rate of economic growth. The first is by enhancing the efficiency of capital allocation. Financial intermediaries and stock markets enable funds to be pooled and channelled to high return projects. The financial system is assumed to facilitate risk sharing and riskreduction through diversification and to prevent liquidation of profitable projects. In particular, a well-functioning financial system supposedly identifies prospective entrepreneurs, effectively evaluates their projects with respect to potential returns and risk, and mobilises resources to the more promising ones. Channelling funds to finance such activities also improves productivity and encourages economic growth.

The other presumption in the literature is that in the presence of global shocks that affect economies, financial development can help different economic units to take advantage of growth opportunities. These shocks create new opportunities for growth in some sectors, which requires re-allocation of resources to these units. With a well-developed financial market this re-allocation process occurs efficiently, and the economy will be able to respond effectively to new growth opportunities.

\subsection{FINANCIAL SECTOR AND ITS DEVELOPMENT}

From all the studies have been conducted with regard to financial sector development, the most inclusive definition for term "financial development" is provided by King and Levine (1993a), Levine (1997), andEllis and Zhu (2004). Putting their definitions together, the financial sector can be called "developed" if the efficiency, stability, and competitiveness of the sector improve, and the range of financial services and the diversity of financial institutions increase. The increase in the amount of money that is intermediated through the financial sector or the capital that is allocated by the private sector are other signs of development in financial markets. Financial sector development requires growth in the volume and sophistication of activities as well as changes in the structure of the market. Generally speaking, as the economy develops, increase in the volume of transactions in the financial sector is expected. 
In terms of structure, traditionally, there are two major types of financial systems: bank-based and market-based systems. In countries with bank-based systems, long term finance is largely provided by banks, while in market-based systems bonds and equity finance play a much greater role. The bank-based theory emphasises the positive role of banks in development and growth. It argues that banks can finance development more effectively than markets in developing economies, and, in the case of state-owned banks, market failures can be overcome and allocation of savings can be undertaken strategically. By contrast, the market-based theory highlights the advantages of well-functioning markets. It is argued that market-based financial systems reduce the inherent inefficiencies associated with banks and are, thus, better in enhancing economic development and growth. Selected countries in this study are South Korea, Hong Kong and United Kingdom that range from bank dominated to market dominated in terms of their financial sector development.

Recent studies, particularly those originated from Endogenous Growth Theory which concentrates on the study of factors affecting long-run growth, have suggested that financial intermediation affects growth through various channels, including through its effects on rates of investment, the efficiency of capital allocation, its impact on productivity growth rate, and the level of savings. The literature on this subject, mostly focused on empirical analysis, has been used by some economists to show that financial sector development has positive effects on steady state growth rates, and that countries with developed financial systems tend to grow faster. Consequently, Endogenous Growth theorists have hypothesised that financial market development creates and leads economic growth. Keynesian macroeconomics, on the other hand, was explicitly focused on a short period during which capital stock was assumed to be fixed, and aggregate demand management is vital for economic growth. The main concentration in their models is on the real side of the economy.

\subsection{RATIONALE OF THE STUDY}

Prior to the Global Financial Crisis (GFC), taking a longer-term view on financial markets was simply a restatement for not worrying about financial market size, structure, and financial market-real economy interaction. Instead the dominated ideology of "free market paradigm" reinstated self-correcting nature of financial sector, so no default was expected. Obviously, GFC placed a high burden of proof on economies held those views.

After the crisis, it became clear that financial markets couldn't be perceived as safe havens any longer. We watched how GFC negatively affected the economies of more than half of countries in the world, more recently; we watched how regional 
financial crisis intensified in the Eurozone. Affected economies underwent large and enduring damages. Governments began to recognise the importance of immediate and substantial actions to overcome the problem by reviewing and reforming financial regulations. The depth and breadth of resources dedicated to analysis and monitoring of financial sector has significantly increased. Moreover, since the crisis a fairly large body of literature had been devoted to the identification of major contributing factors to the GFC. However, the challenge of finding an acceptable solution has proved perplexing. One reason behind this could be that we lack a compass derived from the theory to provide guidance on how financial markets link to the rest of the economy. With so much of innovations and technological progress taking place in the financial markets around the world, it is not astonishing that theory may actually lag behind practice and that there might be misconception among some economists about how financial markets relate to the real side of the economy.

Therefore, it is important to emphasise here that the aim of this research is neither to discuss the lessons available from the experience of the GFC, nor to make recommendations about the breadth and scope of financial regulatory and policy changes that are continuously taking place in the financial sectors. Instead, the purpose of this research is to present a way to make sense of the various strands of growth theories by synthesizing the relevant theories to specify the conditions under which a comprehensive model is found useful (using real data), and to embed financial intermediary variables in a full and open macroeconomic model in order to explain the dynamics of the business cycle influenced by the characteristics of the financial system with the aid of econometric techniques.

The argument put forward by Endogenous Growth theorists is mainly that an intermediation sector permits an economy to reduce the fraction of its savings held in the form of unproductive liquid assets, and to prevent misallocations of invested capital due to liquidity needs. The argument just given suggests that financial intermediaries may naturally tend to alter the composition of investment and savings in a way that is favourable to capital accumulation. Then, since the composition of investment affects real growth rates, intermediaries will tend to promote growth. In existing body of literature in Endogenous Growth theory the analysis on financial intermediation draws heavily on the contributions of the theorists such as Romer (1986), Prescott and Boyd (1987), Rebelo (1987), and Lucas (1988). However it seems that the argument of financial intermediary and the role of financial market development somehow are neglected in mainstream Keynesian and Post-Keynesian economics. This motivates the modelling strategy along with some assumptions derived from the theory of financial intermediation for further investigation of the mainstream Keynesian/Post-Keynesian framework. 
Another problem that is observed in the literature, even those originated from Endogenous Growth theory, is that, although there is a considerable amount of empirical and theoretical literature that hypothesises a positive relationship between financial sector development and economic growth, it is surprising that most of these studies are simply based on a simple causality test between financial development indicators and GDP growth rate. These studies fail to adequately integrate this relationship into a general macro-economic model.

Recent Endogenous Growth studies have suggested that financial intermediation affects growth through various channels, including through its effects on rates of investment, the efficiency of capital allocation, its impact on productivity growth rates, and the level of savings. However, the transmission mechanism has not been tested empirically. In other words, from empirical point of view, we do not know which channels of macroeconomics are affected directly by the development of financial markets which consequently leads to economic development and promotes economic growth, nor whether growth is affected by a higher investment (saving) rate, a better resource allocation (efficiency) and/or productivity growth. This calls for further attempts to construct a model of aggregate demand which integrates financial market development into it.

On the other hand, Post-Keynesian growth theories have been formed from various strands found mainly in the writings of Keynes and Kalecki and stimulated by Harrod's approach which places more emphasis on income distribution. Their macroeconomic models concentrate on the real side of the economy and pay little attention to the financial side, so it seems that the importance of the financial sector and financial intermediaries has been neglected in Post-Keynesian works, and the impact of financial markets has rarely been considered as relevant in their determination of equilibrium conditions, and macroeconomic modelling. They have been criticised from time to time because their models left out any explicit analysis of the monetary and financial aspects. Even though insights into financial impacts have derived from Endogenous Growth theory rather than from standard neo-classical, Keynesian or Post-Keynesian models, nevertheless the author believes that these Post-Keynesian models of economic growth can and should be expanded to include financial variables. This expansion should take into account the role of the banking system and credit and stock market in stimulating aggregate demand.

In addition, there are some other issues that have received little attention, such how financial development affects all sources of economic development, what proxies are best in explaining the degree and level of development in the financial sectors, and finally whether the structure of financial markets matters in the growth process. The empirical analysis of this study provides insights into the functioning of 
the Hong Kong and United Kingdom macro- economy, considering their productive but uneven financial market structure.

In the 20th century economists started arguing that differences in the financial structure of the two countries help explain country's pace of economic growth (Gerschenkron, 1962). The argument is initiated based on the following; bank-based financial system creates strong bonds between banks and industries, which consequently reduce the costs of acquiring information about firms. This makes it easier for the financial system to identify good investments, exert corporate control, and mobilising saving than in countries with a more security and bond market oriented financial system such as England, where the ties between banks and industry are less intimate.

The market-based theory, from the other hand, highlights the advantages of well-functioning markets. Big, liquid and well-functioning markets foster growth and profit incentives, enhance corporate governance and facilitate risk management (Levine, 2000; Beck \& Levine, 2002). Boyd and Smith (1998) assumes that Marketbased financial systems reduce the inherent inefficiencies associated with banks and are, thus, better in enhancing economic development and growth. They demonstrate through a model that allows for financial structures to change as countries go through different stages of development, that countries become more market-based as development proceeds. The bank-based financial system is sometimes viewed as superior to the market-based financial structure in terms of fostering economic growth. However, recent banking problems and financial crisis particularly in East Asian economies and emerging markets which are more bank-based in financial sector have led some to argue that the absence of a credible takeover threat through efficient stock markets has hampered proper corporate governance and competitiveness (King \& Levine, 1994).

Connecting the structure of financial markets to economic performance is not an easy task though and may not enable us to investigate that how well different financial systems function in different countries. In the bank-based financial system, banks may have closer ties with industries and investment projects, Hong Kong financial market is a strong example. Nevertheless, at the same time countries with marketbased financial system may be more capable at providing liquidity and facilitating transactions, which is certainly the case in the UK. 


\subsection{SCOPE OF THE BOOK}

The overarching aim of this research project is to provide an answer to the question of "whether financial system developments and improvements affect real economic activities?" in achieving that objective; six specific objectives are presented in Table 1.

The project sought to investigate these six goals and to examine the key issues associated with the links coexist between real and financial sector development. A comprehensive literature review along with a range of estimation techniques is used investigate simultaneous connections and to capture the relationships and relative penetration of financial markets into the real sector.

\subsection{METHODOLOGICAL APPROACH AND MODELLING FRAMEWORK}

The main focus in this study is to identify channels through which financial sector development influences drivers of economic growth. Therefore, the methodological approach is required to provide a framework and necessary tool to capture the dynamics of the relationship between financial market and economic growth, at the same time try to avoid the drawbacks of hidden endogeneity issue. Therefor a particular emphasis is placed on the formal and exogenous integration of financial market development into a Kaleckian-Post-Keynesian open macroeconomic model. The influence of financial markets on economic development is captured through the inclusion of financial development proxies.

\section{Table 1. Book's objectives}

\begin{tabular}{|l|l|}
\hline Goal 1 & $\begin{array}{l}\text { To examine the role of financial development on the key macroeconomic variables such as Investment, } \\
\text { Saving, and productivity growth in a particular Kaleckian- post Keynesian macroeconomic model. }\end{array}$ \\
\hline Goal 2 & $\begin{array}{l}\text { To present financialsectorprofile and its recent development in three selected countries as case studies } \\
\text { (South Korea, Hong Kong and United Kingdom), to explore their different phases of development } \\
\text { and to briefly discuss their macroeconomic policies, reforms, and regulations implemented in the } \\
\text { last couple of decade. }\end{array}$ \\
\hline Goal 3 & $\begin{array}{l}\text { To capture the contemporaneous relationship between financial sector and real sector development, } \\
\text { using historical data and applying Structural Vector Autoregression modelling technique. }\end{array}$ \\
\hline Goal 4 & $\begin{array}{l}\text { To address the different structures of financial sectors across case study countries, and to investigate } \\
\text { whether the structure of financial system matters for economic growth, and macroeconomic outcomes. }\end{array}$ \\
\hline Goal 5 & $\begin{array}{l}\text { To investigate the speed at which real sector structural adjustments will take place after a structural } \\
\text { shock is imposed on financial market, and to enquire how the real sector reacts to these shocks over } \\
\text { time, using impulse response analysis. }\end{array}$ \\
\hline Goal 6 & $\begin{array}{l}\text { To draw inferences regarding the proportion of the movement in financial indicator due to its own } \\
\text { earlier "shocks" vis-à-vis "shocks'. }\end{array}$ \\
\hline
\end{tabular}


The methodological approach adapted in this exercise is a structural sector autoregression (SVAR) model, which is used to examine the relationship between exogenous financialdevelopment indicators, and a system of equations for key macroeconomic growth indicators, using quarterly data for periods ranging from 1990 to 2010. This is done in a series of steps and pre-analysis testing; first cointegration tests are carried out to determine the existence of long-run relationships between the variables, all of which shed some light on the nature of the relationship among the variables. Second, a Structural VAR model is set up and used, in the first instance, to conduct block exogeneity tests.

These tests are then complemented by an analysis of theimpulse response functions and variance decomposition analysis. By doing so, we account for the simultaneity issue and hope to obtain insights into the significance of financial development indicators in the process of economic growth, by presenting comparative results between three case study countries, namely South Korea, Hong Kong and United Kingdom considering the uneven structure of their financial markets.

The set of long-run determinants of investment, savings and productivity growth in the model is extended to include proxies for financial system developments exogenously, which allows for a more realistic ar iculation of economic relationships. Each endogenous variable is explained by a structural equation that has an error associated with it. The error term for each equation is interpreted as representing an innovation or shock. The full system of equations can be used to simulate the reaction of endogenous variables. The system can also be used to decompose for past influences on macroeconomic fluctuations, including the influence of financial development indicators. The empirical analysis of this study provides insights into the functioning of these three countries' macro-economy. This research also aims to investigate the dynamic responses of the model to shocks in indicators of financial development, and determines whether the effects of such shocks on the long run relations disappear.

\subsection{ORGANISATION OF THE BOOK}

For ease of comprehension, this book has a direct structure in which nine main chapters are distinguished:

Chapter 1 presents the introduction including the definition of financial development and a summary of its origins, briefly, in the history of economic growth and development, plus a statement of the problem and the research objectives of the study. Chapter 2 and 3 provide a comprehensive review of the incorporation of finance into economic growth development and the process by which finance has been released in theoretical frameworks in different school of thoughts. The review 
Figure 1. Steps to theoretical model

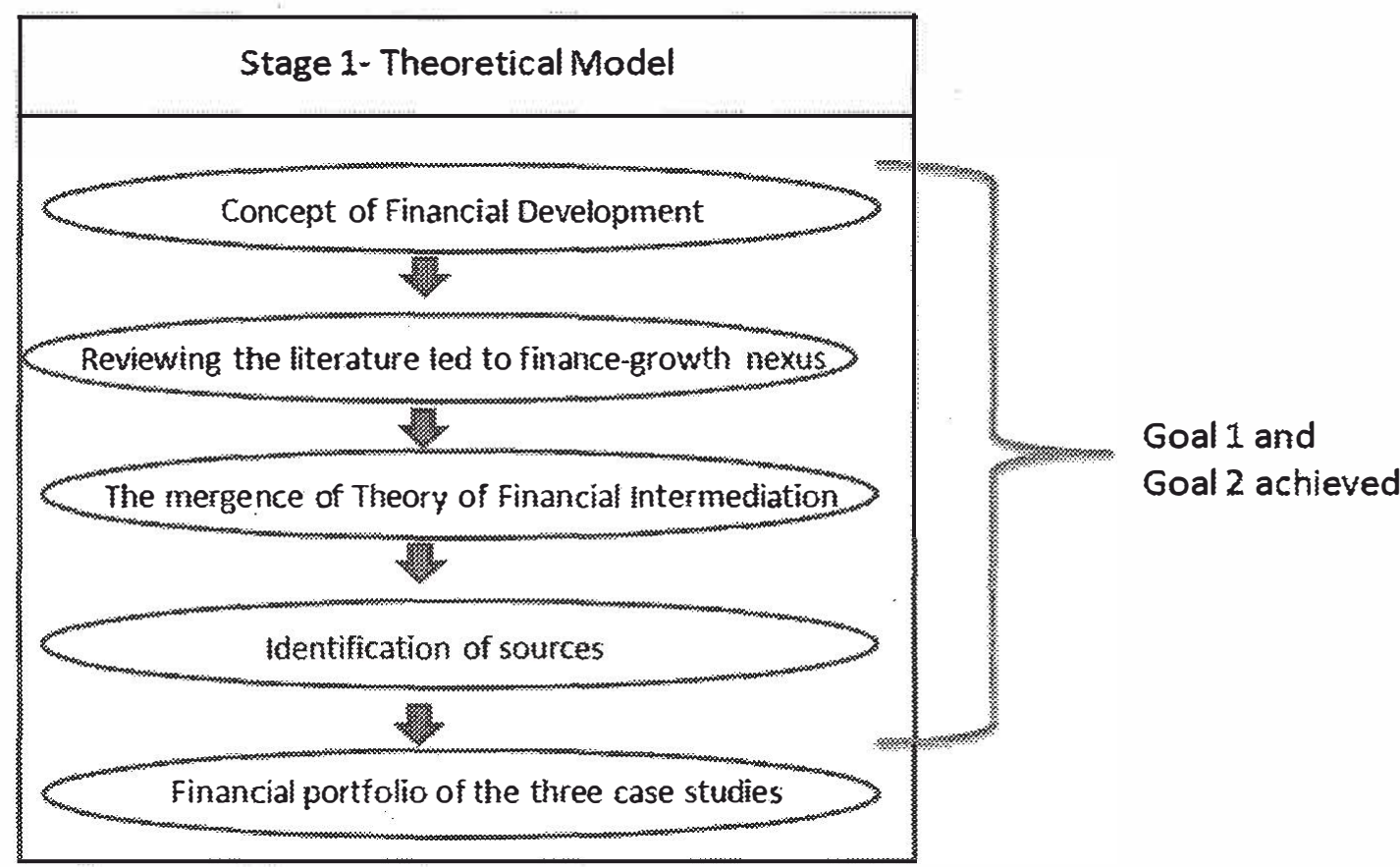

shows how financial aspects gradually found their way into real sector analysis and how they have been treated in different models. The chapter ends with the introduction of the theory of financial intermediary which leads to the question as to whether financial sector development can create economic development. Also the most common indicator of financial development is highlighted.

Since the main objective of this research is to investigate the impact of financial development on economic growth by adopting a Post-Keynesian tradition, Chapter 4 reviews Post-Keynesian growth models and the process by which some financial variables have started to be incorporated into these models. Chapter 5 concentrates on particular Kaleckian-Post-Keynesian macroeconomic models and explains this theoretical framework which forms the basis for our empirical model and testings. Chapter 6 highlights the characteristics, performance and structure of the financial sectors in the case study countries, South Korea, Hong Kong, and United Kingdom, addressing their similarities and diversities, and the latest regulations and reforms that have taken place there in the last couple of decades. The first six chapters help us to achieve Goal 1 and Goal 2 of the research work mentioned earlier.

Chapter 7 presents the results of conducted pre-analysis tests and data characteristic investigations. Empirical tests consist of unit root tests, cointegration tests and causality tests of the variables. Chapter 8 provides the results of simultaneous analysis within a system approach, applying structural vector autoregression methodology. The results from structural vector autoregression enables us to further 
Figure 2. Steps to empirical model

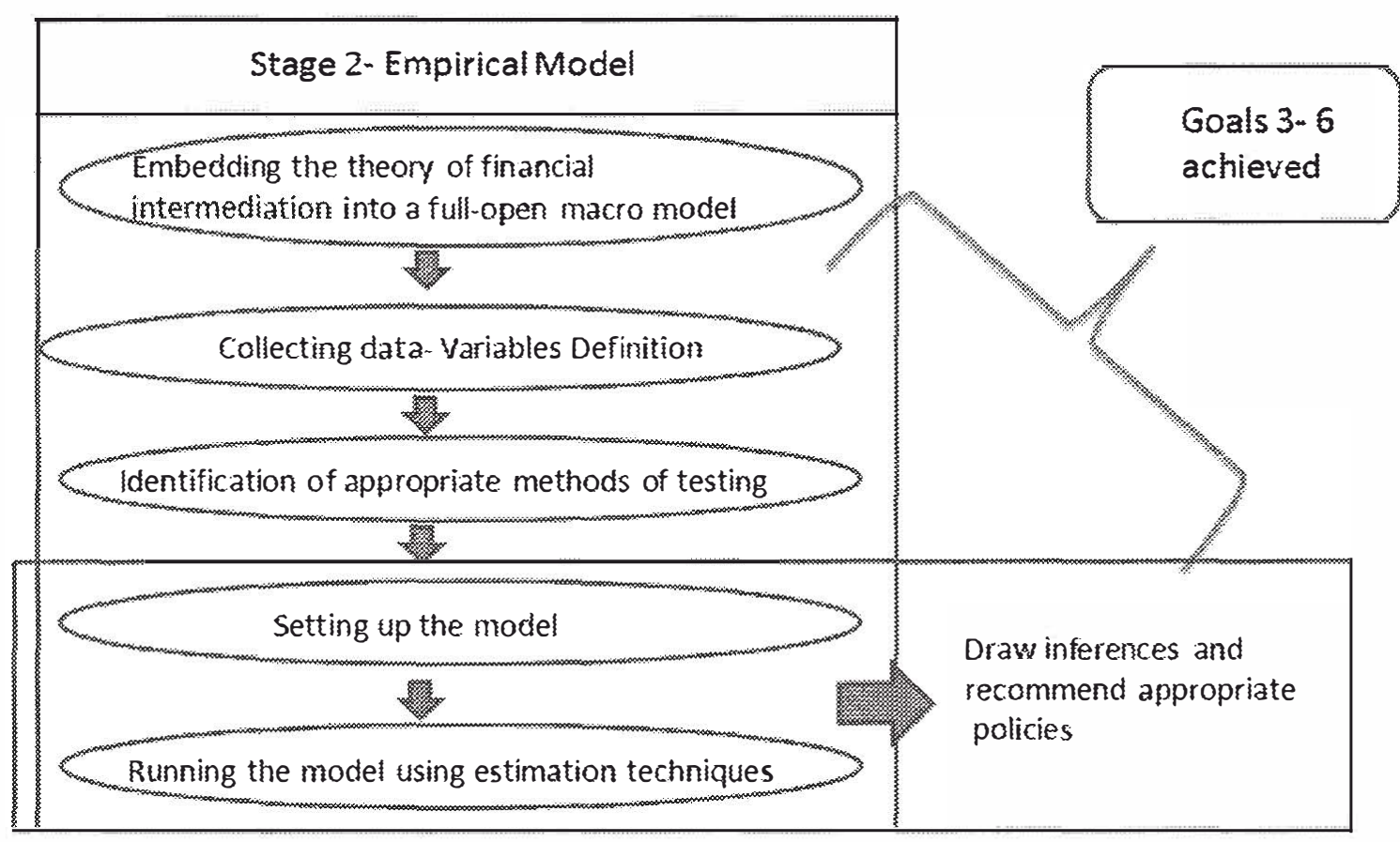

investigate the impact of financial development indicators on the other real sector variables using the impulse response analysis and variance decomposition which their results are presented and discussed in this chapter for all three case study countries. Chapter 9 is the conclusion and summary chapter brings together the major findings of the study and brings out policy implications and recommendations to be followed by these particular countries and some general policy recommendations are drawn. A number of limitations of the study along with suggestions regarding areas of future research are addressed in this chapter as well.

\subsection{SUMMARY OF THE CHAPTER}

The chapter highlights that recent studies, particularly those originating from modern growth theory, have suggested that financial intermediation affects growth through various channels, However, within the Post-Keynesian tradition, while the role of financial matters is put forward, macroeconomic models concentrate on the real sector analysis only. Moreover, in this chapter the definition of financial sector development is provided. The chapter briefly discusses that the financial sector can be called developed if the efficiency, stability, and competitiveness of the sector improves the range of financial services, the volume of transaction diversity of financial institution increases and sophistication of activities as well as changes in the structure of the market are observed. 
The research question arose, that is whether financial development affects real economic activities and does the structure of the financial system matter for economic growth outcome. Accordingly, the main research objective is to investigate the impact of financial sector development on real sector key indicators such as investment, savings and productivity growth. The significance of this study is addressed in terms of integrating the financial sector with the real sector in a comprehensive macroeconomic model in Post-Keynesian fashion, and in terms of the econometric techniques, which enable the research to address simultaneity issues among variables. Accordingly, in this book, the fundamental analytical ambition is to explain the simultaneous interaction between macroeconomic indicators and financial market variables, and to reach a better understanding of instantaneous and synchronised relations between these indicators.

\section{REFERENCES}

Beck, T., \& Levine. (2002). Industry Growth and Capital Allocation: Does Having a Market- or Bank-Based System Matter? Journal of Financial Economics, 64, 147-180. doi:10.1016/S0304-405X(02)00074-0

Boyd, J. H., \& Smith. (1998). The evolution of debt and equity markets in economic development. Economic Theory, 12, 519-560. doi:10.1007/s001990050234

Caprio, G. (1998). Banking on crises: Expensive lessons from recent financial crises (Policy Research Working Paper, WPS1979). Washington, DC: The World Bank.

Ellis, H., \& Zhu, X. (2004). Using financial market information to enhance Canadian fiscal policy (Working Papers 1041). Queens University.

Gerschenkron, A. (1962). Economic backwardness in historical perspective: A book of essays. Cambridge, MA: Belknap Press of Harvard University Press.

King, R. G., \& Levine. (1993). Finance and growth: Schumpeter might be right. The Quarterly Journal of Economics, 108, 717-738. doi:10.2307/2118406

King, R. G., \& Levine. (1994). Capital fundamentalism, economic development and economic growth. Carnegie-Rochester Conference Series on Public Policy, 40, 259-292. doi:10.1016/0167-2231(94)90011-6

Levine, R. (1997). Financial development and growth: Views and agenda. Journal of Economic Literature, 35, 688-726. 
Levine, R. (2000). Bank-based or Market-based Financial Systems: Which is Better? University of Minnesota.

Prescott, E., \& Boyd, J. H. (1987). Dynamic Coalitions: Engines of Growth. The American Economic Review, 77(2), 63-67.

Rajan, R. (2005). Skewed incentives for investment managers may be adding to global financial risk. Finance \& Development, 42(3).

Rajan, R. G., \& Zingales. (2003). Saving capitalism from the capitalists. New York, NY: Random House.

Rebelo, S. (1987). Long Run Policy Analysis and Long Run Growth Manuscript. Rochester, NY: Univ. Rochester.

Romer, P. M. (1986). Increasing returns and long-run growth. The Journal of Political Economy, 94(5), 1002-1037. doi:10.1086/261420

Shiller, R. J. (2003). From efficient market theory to behavioural finance. The Journal of Economic Perspectives, 17, 83-104. doi:10.1257/089533003321164967

\section{KEY TERMS AND DEFINITIONS}

Endogenous Growth: An economic theory that holds the proposition that economic growth is achieved as the result of endogenous forces and not exogenous factors.

Financial Sector Development: A process through which financial instruments, financial markets, and financial intermediaries work together to reduce the costs of information, and transactions, and facilitate directing savings to productive investment projects.

Financial Sector: One of the most important sectors of an economy which consists of (but not limited to) banks, investment funds, insurance companies.

GFC: Global financial crises of 2007-08 that caused in the collapse of major financial institutions around the world, resulting in foreclosures and prolonged unemployment.

Post Keynesians: An economic school of thoughts that origins from the works of John Maynard Keynes and influenced by works of Michael Kalecki, Joan Robinson, and Nicholas Kaldor. 


\section{About the Author}

Taha Chaiechi is currently a senior lecturer in the Discipline of Economics, School of Business at the James Cook University, Australia. She received her doctorate in economics in 2009 from University of Newcastle in Newcastle, Australia. Dr. Chaiechi believes in the principles of effective demand and that demand matters in both the short-run and long-run. Through her research, she actively pursues innovative empirical objectives aimed at shedding light on contemporary economic problems and issues. Dr. Chaiechi's works address an array of practical areas, including the macroeconomic effects of events, health economics, and environmental and climate change economics. She is committed to the ideal that the accumulative development of economic theory is only possible when that theory is continuously examined in terms of its capacity to both explain the real world and to provide reliable recommendations to public policy. Accordingly, her work is methodological in nature, driven by the need to provide a method to answer important real world questions. 